\title{
Effect of Emission Value for Land Surface Temperature on Landsat Image 7 ETM+
}

\author{
A Sediyo Adi Nugraha \\ \{adi.nugraha@undiksha.ac.id\} \\ Universitas Pendidikan Ganesha, Indonesia
}

\begin{abstract}
This research aims to know the impact of land surface temperature value with the use of emissions or not. Emission is essential because emissions become decisive as a result of land surface temperatures. The method used is processing Landsat 7 ETM+ imagery with radiometric and atmospheric correction and combining it with the maximum likelihood of getting land cover. The classification of land cover is essential because that reflects the emission value. The results showed that land surface temperature with emission has more near with conditions in the field than land surface temperature without emission. The most significant difference in land surface temperature in land cover is seven degrees Kelvin $\left(7^{\circ} \mathrm{K}\right)$, and the lowest is one degree Kelvin $\left(1^{\circ} \mathrm{K}\right)$. The analysis concluded that the use of emissions in Landsat 7 ETM+ imagery is necessary and must be done to get the land surface temperature value.
\end{abstract}

Keywords: Landsat 7 ETM+; LST; Emission

\section{Introduction}

The Land Surface Temperature (LST) has been used several variables in specific analyses such as; drought, urban heat island, and forest fires [1]-[4]. The acquisition of information related to surface temperature is made manually with temperature measurement, and it has a deficiency when the area to be monitored is extensive. Therefore, the utilization of remote sensing imagery in obtaining information related to surface temperature continues to increase for other research. Landsat image is one of the images that can provide information related to land surface temperature with its thermal bands [5]-[7].

Landsat development now on Landsat $8 \mathrm{OLI} / \mathrm{TIRS}$ and Landsat $7 \mathrm{ETM}+$, which are still used for land surface temperature information. Landsat 8 OLI/TIR developed split windows algorithm method that combines two thermal bands, band 10, and band 11 [8]-[12]. Different on Landsat $7 \mathrm{ETM}+$ has two similar thermal bands, but land surface temperature information uses band 6 high gain. The selection of the band 6 high gain was influenced by the use of emissions, which is the conversion value to determine the object's land surface temperature. The value of emissions has a difference to land cover so that it is based on the value of certain types of land cover that do not have a specific emission value and follow similar emission values [6], [13], [14]. Landsat $7 \mathrm{ETM}+$ requires identification related to emissions because the formulas and algorithms used based on the Handbook Landsat 7 ETM+ [7] differ from the algorithms that have been done by several studies [15]. In contrast, Landsat 8 OLI/TIRS has a more stable 
method of obtaining surface temperature information because it uses two thermal bands [16][20].

This research is fundamental because the land surface temperature has many applied for other analyses. Therefore, this research's objective is to know how much influence of emissions on land surface temperature processing in Landsat 7 ETM + imagery. Besides, this research is expected to provide a role as a consideration for the acquisition of land surface temperature information.

\section{Methodology}

\section{Study Area}

Purworejo regency is one of the districts in Central Java Province, located between 109 o 47'28" to 110 o 8'20" East Longitude and between $7^{\circ} 32^{\prime \prime}$ to $7^{\circ} 54^{\prime \prime}$ South Latitude. The north of Purworejo regency borders Wonosobo and Magelang Regency, and the south borders the Indonesian Ocean. The west is bordered by Kebumen Regency, and the east borders the area of the Special Region of Yogyakarta, precisely Kulonprogo Regency. Purworejo regency is still much-having farmland that varies from plantations and rice fields with quite varied topographic conditions in the form of coastal areas, lowlands, to mountains so that it can have different levels of soil moisture - different as in areas of land where there are various kinds of land cover will provide different surface soil moisture [21], [22].

\section{Remote Sensing Data}

Landsat 7 ETM+ imagery can be obtained for free on the official website by USGS http://usgs.gov/. Landsat 7 ETM+ was processing with pre-processing such as; Correction Radiometric and Atmospheric, then cropping data for all band except band 8 . The radiometric correction process is carried out by changing the pixel value to the radian and reflectance values. Meanwhile, the atmospheric correction process uses the Dark Pixel Subtraction (DOS) method developed by Chaves [23].

This research uses primary data, which is the leading data that is Landsat 7 ETM+ imagery. The research stage is shown in Figure 1.

\section{Brightness Temperature}

Landsat 7 ETM+ image processing using a band 6 high gain. The radiometric correction process used is radian correction developed by USGS [7] as in Equation (1).

$$
L \lambda=\frac{L \text { Max }-L \text { Min }}{(Q C A L \text { Max }- \text { QCAL Min })} x(\text { QCAL }- \text { QCAL Min })+\text { L Min }
$$

Where Lmax and Lmin can be obtained from Table 1; QcalMax is spectral value Landsat 7 ETM+; QcalMin is Zero (0). Brightness temperature band 6 data processing using Equation (2) developed by USGS (2010). The K1 and K2 values are calibration constants obtained from the Landsat 7 ETM+ image handbook; $\mathrm{L} \lambda$ is the radiance value of Landsat $7 \mathrm{ETM}+$.

$$
\operatorname{Trad}=\mathrm{K}_{2} / \ln \left[\left(\mathrm{K}_{1} / \mathrm{L} \lambda\right)+1\right]
$$


Brightness temperature has a land surface temperature value, but it is not a temperature object because that value is not radiance temperature, just kinetic temperature [13]. Some research uses this algorithm to get land surface temperature value and uses it for its final temperature.

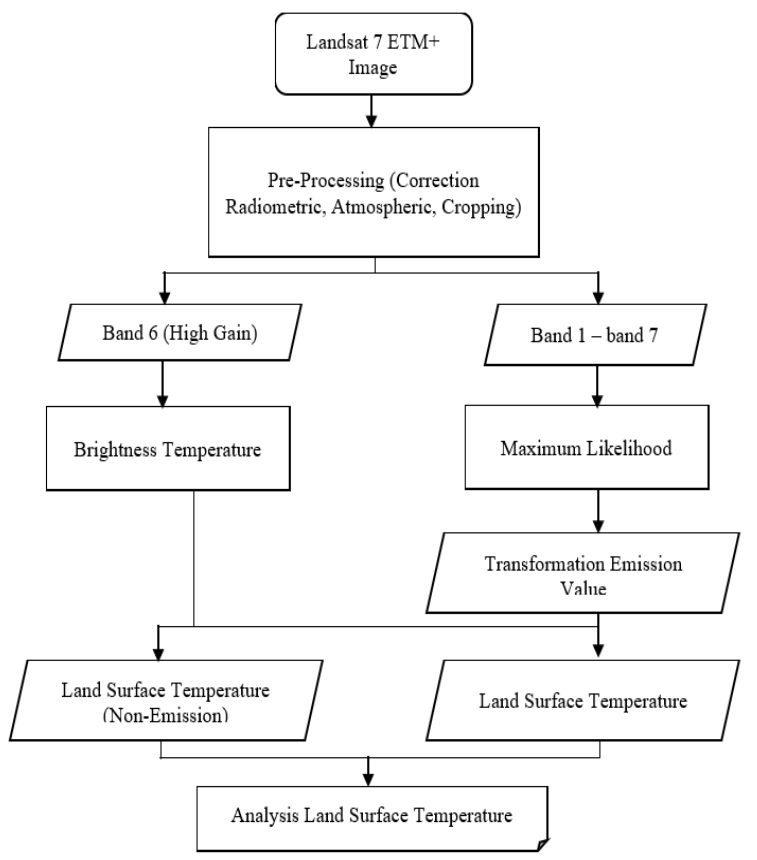

Fig. 1. Research Flowchart

Table 1. Spectrum Radiance ETM+

\begin{tabular}{ccccc}
\hline \multirow{2}{*}{$\begin{array}{c}\text { Number } \\
\text { Band }\end{array}$} & \multicolumn{2}{c}{ LOW GAIN } & \multicolumn{2}{c}{ HIGH GAIN } \\
\cline { 2 - 5 } & L MIN & L MAX & L MIN & L MAX \\
\hline $\mathbf{1}$ & $-6,2$ & 293,7 & $-6,2$ & 191,6 \\
\hline $\mathbf{2}$ & $-6,4$ & 300,9 & $-6,4$ & 196,5 \\
\hline $\mathbf{3}$ & $-5,0$ & 234,4 & $-5,0$ & 152,9 \\
\hline $\mathbf{4}$ & $-5,1$ & 241,1 & $-5,1$ & 157,4 \\
\hline $\mathbf{5}$ & $-1,0$ & 47,57 & $-1,0$ & 31,06 \\
\hline $\mathbf{6}$ & 0,0 & 17,04 & 3,2 & 12,65 \\
\hline $\mathbf{7}$ & 0,4 & 16,54 & 0,4 & 10,80 \\
\hline $\mathbf{8}$ & $-4,7$ & 243,1 & $-4,7$ & 158,3 \\
\hline
\end{tabular}

Source: [7] 


\section{Maximum Likelihood}

Landsat 7 ETM+ image processing for image classification using the maximum likelihood method is a supervised category. This method has excellent accuracy to get the land cover classification [24]. Land-use is used for determining the emission value shown in Table 2. Meanwhile, the change land-use to emission value using ENVI application to have an emission image.

Table 2. Type of Land-Use with Emission

\begin{tabular}{ccc}
\hline No & LandUse & Emission \\
\hline $\mathbf{1}$ & Built-up & 0.97 \\
\hline $\mathbf{2}$ & Built-up with Vegetation & 0.96 \\
\hline $\mathbf{3}$ & High Vegetation & 0.99 \\
\hline $\mathbf{4}$ & Moderate Vegetation & 0.96 \\
\hline $\mathbf{5}$ & Low Vegetation & 0.96 \\
\hline $\mathbf{6}$ & No Vegetation & 0.92 \\
\hline $\mathbf{7}$ & Wet Soil & 0.95 \\
\hline $\mathbf{8}$ & Dry Soil & 0.92 \\
\hline $\mathbf{9}$ & Body of Water & 0.98 \\
\hline Source: Processing Data (2011) &
\end{tabular}

\section{Land Surface Temperature (LST)}

The processing surface temperature method uses the emission value developed by Curran [13] as in Equation (3). The value of $\varepsilon$ is the emission value, and Tkin is the value of the brightness temperature Landsat $7 \mathrm{ETM}+$ band 6 . The difference in the value of land surface temperature between kinetic temperature and radiance temperature is one degree $\left(1^{\circ}\right)$ [25].

$$
\operatorname{Trad}=\epsilon^{1 / 4} \text {. Tkin }
$$

\section{Result and Discussion}

Analysis of land surface temperature between brightness temperature and the land surface temperature has a significant difference value (Table 3 ). The difference value for land surface temperature is very high on seven degrees and very low on one degree. The brightness temperature always increases the value of temperature from land surface temperature and proves the theory about radiance temperature and kinetic temperature [13]. Cause the difference value of temperature from the processing of Landsat 7 ETM+ uses pixel as object analysis and uses the measurement of object reality such as; vegetation, soil, rooftop, and water. Also, the survey for measurement temperature must be the same time as the Landsat 7 ETM+ image take a record. This condition is essential because of the temperature changes with the sun's condition, especially weather and its application for all land surface temperature [12]. Land cover is not 
affected by emission values because the high emission value and low emission value get the same difference temperature value is seven degrees $\left(7^{\circ}\right)$. Meanwhile, one class in land cover always has a different temperature that causes the field's condition.

Table 3. The difference in Surface Temperature to Emission Value

\begin{tabular}{|c|c|c|c|c|c|c|}
\hline \multicolumn{2}{|l|}{ No } & \multirow[t]{2}{*}{ Land Cover } & \multirow{2}{*}{$\begin{array}{c}\text { Emission } \\
\text { Value }\end{array}$} & \multirow{2}{*}{$\begin{array}{c}\text { Land } \\
\text { Surface } \\
\text { Temperature } \\
\text { (Kelvin)/ } \\
\text { Emission } \\
\end{array}$} & \multirow{2}{*}{$\begin{array}{l}\text { Brightness } \\
\text { Temperature } \\
\text { (Kelvin)Non- } \\
\text { Emission }\end{array}$} & \multirow[t]{2}{*}{ Difference } \\
\hline $\begin{array}{l}\text { Class of } \\
\text { Landcover }\end{array}$ & Sort & & & & & \\
\hline \multirow[t]{4}{*}{1} & 1 & Built-up & 0.97 & 295 & 301 & 6 \\
\hline & 2 & Built-up & 0.97 & 303 & 306 & 3 \\
\hline & 3 & Built-up & 0.97 & 301 & 307 & 6 \\
\hline & 4 & Built-up & 0.97 & 295 & 302 & 7 \\
\hline \multirow[t]{5}{*}{2} & 5 & $\begin{array}{l}\text { Built-up with } \\
\text { Vegetation }\end{array}$ & 0.96 & 299 & 301 & 2 \\
\hline & 6 & $\begin{array}{l}\text { Built-up with } \\
\text { Vegetation }\end{array}$ & 0.96 & 296 & 300 & 4 \\
\hline & 7 & $\begin{array}{l}\text { Built-up with } \\
\text { Vegetation }\end{array}$ & 0.96 & 298 & 301 & 3 \\
\hline & 8 & $\begin{array}{l}\text { Built-up with } \\
\text { Vegetation }\end{array}$ & 0.96 & 298 & 300 & 2 \\
\hline & 9 & $\begin{array}{l}\text { Built-up with } \\
\text { Vegetation }\end{array}$ & 0.96 & 299 & 302 & 3 \\
\hline \multirow[t]{3}{*}{3} & 10 & $\begin{array}{l}\text { Moderate } \\
\text { Vegetation }\end{array}$ & 0.96 & 297 & 299 & 2 \\
\hline & 11 & $\begin{array}{l}\text { Moderate } \\
\text { Vegetation }\end{array}$ & 0.96 & 295 & 301 & 6 \\
\hline & 12 & $\begin{array}{l}\text { Moderate } \\
\text { Vegetation }\end{array}$ & 0.96 & 297 & 300 & 3 \\
\hline \multirow[t]{3}{*}{4} & 13 & Low Vegetation & 0.96 & 302 & 305 & 3 \\
\hline & 14 & Low Vegetation & 0.96 & 298 & 301 & 3 \\
\hline & 15 & Low Vegetation & 0.96 & 298 & 301 & 3 \\
\hline \multirow[t]{4}{*}{5} & 16 & No Vegetation & 0.92 & 302 & 304 & 2 \\
\hline & 17 & No Vegetation & 0.92 & 298 & 302 & 4 \\
\hline & 18 & No Vegetation & 0.92 & 299 & 302 & 3 \\
\hline & 19 & No Vegetation & 0.92 & 295 & 302 & 7 \\
\hline \multirow[t]{3}{*}{6} & 20 & Wet Soil & 0.95 & 295 & 301 & 6 \\
\hline & 21 & Wet Soil & 0.95 & 296 & 300 & 4 \\
\hline & 22 & Wet Soil & 0.95 & 299 & 300 & 1 \\
\hline \multirow[t]{3}{*}{7} & 23 & Dry Soil & 0.92 & 306 & 308 & 2 \\
\hline & 24 & Dry Soil & 0.92 & 305 & 306 & 1 \\
\hline & 25 & Dry Soil & 0.92 & 307 & 308 & 1 \\
\hline
\end{tabular}




\begin{tabular}{lllllll}
\hline $\mathbf{8}$ & 26 & High Vegetation & 0.99 & 298 & 301 & 3 \\
\cline { 2 - 7 } & 27 & High Vegetation & 0.99 & 297 & 300 & 3 \\
\hline \multirow{2}{*}{$\mathbf{2 8}$} & High Vegetation & 0.99 & 293 & 299 & 6 \\
\hline & 29 & Body of Water & 0.98 & 298 & 300 & 2 \\
\hline & 30 & Body of Water & 0.98 & 298 & 300 & 2
\end{tabular}

Source: Processing Data, 2015.

The result of land surface temperature is proving; one land cover has a different value of temperature. Built-up and no vegetation has a high temperature than another land cover. The built-up has a high temperature because density of settlement made land surface temperature increase, which could make urban heat island in the future [2]. While other land covers such as; vegetation make temperature decrease because the healthy vegetation with their density always reflects the sun's energy. This condition different from water. It absorbs the energy of the sun and cannot reflect directly. This condition can know the spread of land surface temperature on the field (Fig.2) influence of emission.

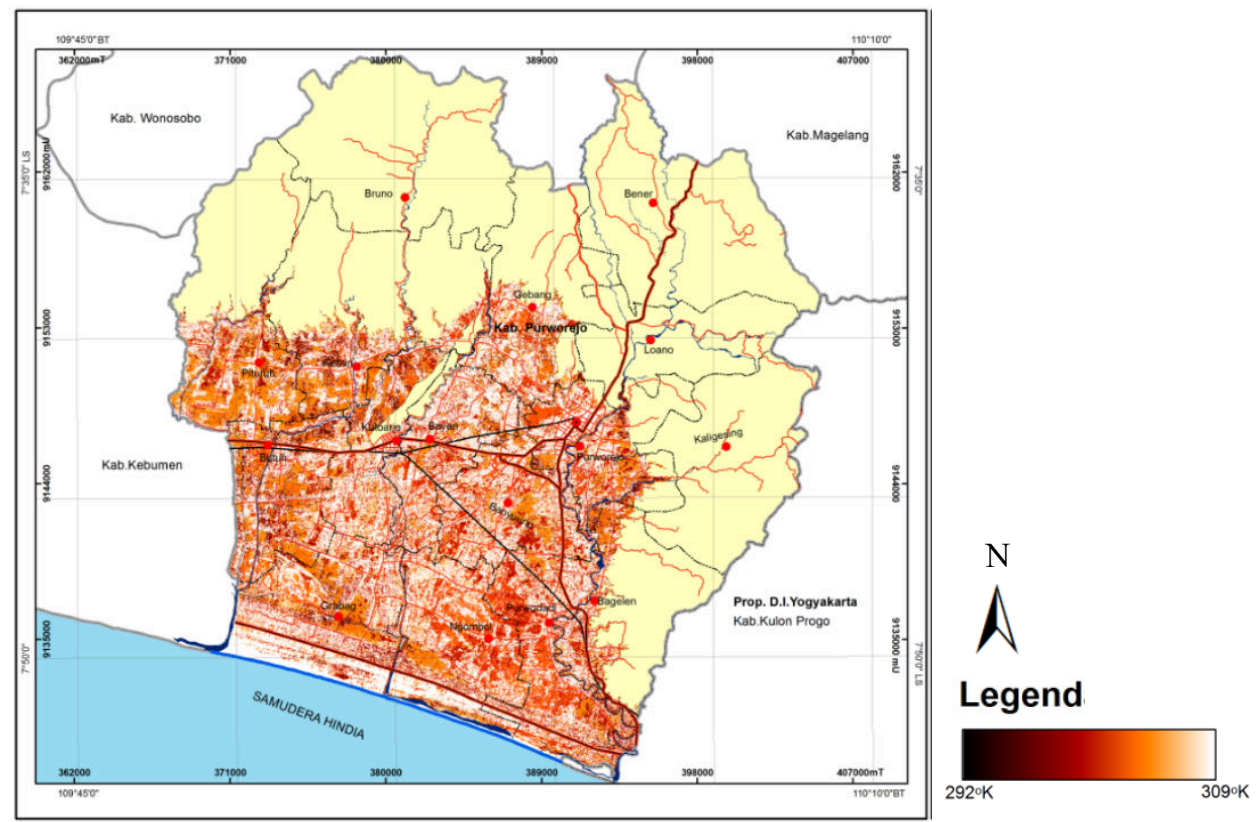

Fig. 2. The Result of Land Surface Temperature with Emission Value

Emission proof is essential to extraction information for land surface temperature, especially for Landsat image or other thermal band images. The calculated emission has several methods. Tursilowati et al. [15] using emission from vegetation index and give the result approaching the condition of the field for extraction land surface temperature. The method for calculating emission need more research to know the impact of land surface temperature. Therefore, land surface temperature without emission is not the real temperature object and cannot be used for anything analysis because increasing the temperature and anomaly. 


\section{Conclusion}

Land Surface Temperature (LST) with emission and LST without emission has a high difference for one class in land cover. This class indicates that land surface temperature processing must use the emission value because it is near the field's land surface temperature. Emission proves LST needs this value to extraction temperature, although it can be obtained from land cover or another method. The difference of temperature values affected by comparing analysis where Landsat using pixel and measurement using a real object. Further study, especially on emissions extraction, to be compared with other methods for calculating emission. These impact value emissions are significant because studies on land surface temperatures always focus, and many applied to use.

\section{References}

[1] A. S. A. Nugraha, " Utilization of Multi-Level Remote Sensing Imagery for Drought Change Mapping (Cases in East Java Province) (In Bahasa).” Universitas Gadjah Mada, 2016.

[2] A. S. A. Nugraha and D. M. Atmaja, "The Application of Multi-Temporal Remote Sensing Images to Detect Urban Heat Island ( UHI ) for Land use Changes in Buleleng District (In Bahasa)," Maj. Ilm. Globe, vol. 22, no. 2, pp. 71-82, 2020.

[3] N. I. Fawzi and R. H. Jatmiko, "Heat Island Detection in Coal Mining Areas using Multitemporal Remote Sensing," Proc. 36th Asian Conf. Remote Sens. (ACRS 2015), Metro Manila, Philipp., no. October 2015, 2015.

[4] N. I. Fawzi, “ Measuring Urban Heat Island using Remote Sensing, Case of Yogyakarta City (In Bahasa),” Maj. Ilm. Globe, vol. 19, no. 2, pp. 195-206, 2017.

[5] Sutanto, Remote Sensing Volume I (In Bahasa). Yogyakarta, 1986.

[6] Sutanto, Remote Sensing Volume II (In Bahasa). Yogyakarta: Gadjah Mada University Press, 1987.

[7] U.S. Geology Survey Department, "Landsat 7 Science Data Users Handbook.” 2010, doi: 10.1001/archinternmed.2011.606.

[8] J. A. Sobrino, J. El Kharraz, and Z. L. Li, "Surface temperature and water vapour retrieval from MODIS data,” Int. J. Remote Sens., vol. 24, no. 24, pp. 5161-5182, 2003, doi: 10.1080/0143116031000102502.

[9] Z. Qin, G. Dall, A. Karni, and P. Berliner, "Derivation of split window algorithm and its sensitivity analysis for retrieving land surface temperature from NOAA-advanced very high resolution radiometer data," J. Geophys. Res., vol. 106, no. 19, pp. 22655 22670, 2001, doi: 10.1029/2000JD900452.

[10] A. S. A. Nugraha, T. Gunawan, and M. Kamal, "Comparison of Land Surface Temperature Derived from Landsat $7 \mathrm{ETM}+$ and Landsat $8 \mathrm{OLI} / \mathrm{TIRS}$ for Drought Monitoring," IOP Conf. Ser. Earth Environ. Sci., vol. 313, no. 1, pp. 0-10, 2019, doi: 10.1088/1755-1315/313/1/012041.

[11] A. S. A. Nugraha, T. Gunawan, and M. Kamal, "Downscaling land surface temperature on multi-scale image for drought monitoring," in Sixth Geoinformation Science Symposium, 2019, no. November, p. 6, doi: 10.1117/12.2544550.

[12] A. S. A. Nugraha, " The Application of Split-Windows Algorithm (SWA) Methods on Landsat 8 Using Modis Terra Water Vapor (In Bahasa)," geomatika, vol. 25, no. 1, pp. 9-16, 2019, doi: http://doi.org/10.24895/JIG.2019.25-1.877. 
[13] Curran, Principle of Remote Sensing. London: Longman, 1985.

[14] T. M. Lillesand and R. W. Kiefer, Remote Sensing And Image Interpretation. Yogyakarta: Gadjah Mada University Press, 1979.

[15] L. Tursilowati, J. Tetuko, S. Sumantyo, H. Kuze, and E. S. Adiningsih, "Relationship between Urban Heat Island Phenomenon and Land Use/Land Cover Changes in Jakarta - Indonesia," J. Emerg. Trends Eng. Appl. Sci., vol. 3, no. 4, pp. 645-653, 2015.

[16] C. Du, H. Ren, Q. Qin, J. Meng, and S. Zhao, "A practical split-window algorithm for estimating land surface temperature from landsat 8 data," Remote Sens., vol. 7, no. 1, pp. 647-665, 2015, doi: 10.3390/rs70100647.

[17] O. Rozenstein, Z. Qin, Y. Derimian, and A. Karnieli, "Derivation of land surface temperature for landsat-8 TIRS using a split window algorithm," Sensors (Switzerland), vol. 14, no. 4, pp. 5768-5780, 2014, doi: 10.3390/s140405768.

[18] Z. Wan and J. Dozier, "A generalized split-window algorithm for retrieving landsurface temperature from space," IEEE Trans. Geosci. Remote Sens., vol. 34, no. 4, pp. 892-905, 1996, doi: 10.1109/36.508406.

[19] K. Watson, "Two-temperature method for measuring emissivity," Remote Sens. Environ. - Remote SENS Env., vol. 42, pp. 117-121, 1992.

[20] A. R. Harris and I. M. Mason, "An extension to the split-window technique giving improved atmospheric correction and total water vapour," Int. J. Remote Sens., vol. 13, no. 5, pp. 881-892, Mar. 1992, doi: 10.1080/01431169208904161.

[21] Department Of Public Housing And Residential Areas, "Central Java Goverment," 2020. http://si.disperakim.jatengprov.go.id/umum/detail_kondisi_geo/27.

[22] S. A. Nugroho, “Analysis of Surface Soil Moisture Through Landsat 7 ETM+ Imagery in Purworejo Regency Plain Area (In Bahasa)," Universitas Muhammadiyah Surakarta, 2011.

[23] J. Chavez, "Animproved dark-object subtraction technique for atmospheric scattering correction of multispectral data," Remote Sens. Environ., vol. 24, pp. 159-279, 1988.

[24] R. Septiani, I. P. A. Citra, and A. S. A. Nugraha, " Comparison of Supervised Classification and Unsupervised Classification Method to Land Cover in Buleleng Regency (In Bahasa)," J. Geogr. Media Inf. Pengemb. dan Profesi Kegeografian, vol. 16, no. 2, pp. 90-96, 2019, doi: 10.15294/jg.v16i2.19777.

[25] P. N. Slater, Remote Sensing: Options and Optical Systems. Massachusetts; London: Addison-Wesley Reading, 1980. 